\title{
THE EFFECT OF AN INTRA-UTERINE SUTURE ON FERTILITY IN THE RAT
}

\author{
F. HAVRÁNEK, H. DYKOVÁ AND M. TICHÝ \\ Institute for the Care of Mother and Child, \\ Prague 4, Podoli, Czechoslovakia
}

(Received 18th April 1966, revised 1st Fuly 1966)

\begin{abstract}
Summary. A nylon suture inserted into one uterine horn prevented implantation in the same horn in $60.7 \%$ of rats. In the remainder which showed implantations in the treated horn, the number of implantation sites was significantly lower than in control horns. Some of these embryos were underdeveloped or dying.

Histologically it could be shown that in some rats implantations occur even if the suture passes through the lumen of the horn.

The leucocytic infiltration of the endometrium was associated with prevention of implantation, but it occurred, albeit to a lesser extent, also in rats with implantations in treated horns.
\end{abstract}

\section{INTRODUCTION}

The antifertility effect of intra-uterine sutures differs according to the experimental animal used. In rabbits, a suture affects the number of implantations and has an unfavourable effect on the further course of gestation (Adams \& Eckstein, 1965a, b). Different types of sutures had different effects. In rats, silk sutures completely prevent implantation (Doyle \& Margolis, 1963, 1964, 1965; Margolis \& Doyle, 1964; Kar, Kamboj \& Datta, 1964; Kar, Kamboj, Goswami \& Chowdhury, 1965). Greenwald (1965), however, found that in some rats implantation does occur in the horns with sutures. It depended on whether the suture passed into the lumen of the horn. Prevention of implantation was accompanied by a leucocytic infiltration in the lumen and the wall of the treated horn. The present paper deals with the relationship between the site of the suture and the occurrence of leucocytic infiltration and the prevention of fertility.

\section{MATERIALS AND METHODS}

A total of thirty-five female rats of our own Wistar strain, weighing 170 to $240 \mathrm{~g}$, was used. The suture was made with a black monofilament nylon fibre ('Orsilon' nylon of Czechoslovak origin, strength $0.075 \mathrm{~mm}$ ) inserted with an atraumatic needle. The procedure was as follows: the abdomen was opened along its midline under ether anaesthesia and the antimesometrial surface of the 
right uterine horn was exposed. In five animals sutures were made according to the 'free-ending' technique of Doyle \& Margolis (1963) and in thirty they were fully attached in such a way that they were inserted into the uterine lumen and brought out approximately 5 to $8 \mathrm{~mm}$ above the initial site of entry. The control horn was pierced in the same way, but no thread was placed in it. Sutures were inserted in the middle third (ten rats) or distal third (twenty-five rats) of the uterine horn. Ten to 14 days later the females were mated with fertile males. The day on which spermatozoa were recovered in the vaginal smears was designated as Day 1 of pregnancy.

A second laparotomy was usually performed 10 to 16 days p.c. and the number of embryos was counted in the treated and the contralateral uterine horns. In sixteen rats one or both uterine horns were removed on that day and fixed in Bouin's solution and subsequently sectioned at $7 \mu$ and stained with haematoxylin and eosin. In twenty-four rats the number of corpora lutea was counted through a lens during laparotomy. In five animals the suture was removed on Day 3 of pregnancy.

\section{RESULTS}

The results refer only to twenty-eight of the thirty-five experimental animals in which the suture had been retained in the uterus. Findings in the remaining seven females have not been included in the following analyses.

Implantations and corpora lutea in rats with the suture in situ

In twenty-eight animals the suture was found to be in place when the abdomen was opened and explored. In seventeen of them $(60.7 \%)$ the suture had prevented implantation, but in eleven $(39.3 \%)$ implantations had occurred in the treated horns. Retarded or degenerating implantations are included in the total number of implantations. In one rat (No. 28) two implantations were found in the treated horn and none in the control horn (Table 1).

In those animals in which implantation occurred in the treated horn, their number was $3 \cdot 1$, compared with 4.9 in the control horn (see Table 1). According to Wilcoxon's test (Wilcoxon, 1945) this difference is statistically significant $(P=0.02)$. Thus, the thread had a partial antifertility effect, even though it does not completely prevent implantation (Pl. 1, Figs. 1a, b).

Localization of implantation sites with regard to position of the suture. In eight rats the embryos were located between the utero-tubal junction and the thread (henceforth called 'above' the thread). The total number of such implantation sites was twenty-six. In two animals implantations were found 'below' the thread (altogether three implantation sites). In one rat four implantation sites were 'above' and one 'below' the thread.

On the sutured side small (perhaps retarded) or degenerating implantations (with haemorrhages) were found in four rats, a total of ten sites. A similar picture was never seen on the control side. This also indicates an impairment of fertility as a result of the presence of the suture. The number of rats with such abnormal implantations was too small to establish any correlation between their number and the stage of pregnancy. 
Corpora lutea were found on both sides regardless of whether a uterine thread was present or not (Table 1). No difference was found between the mean number of corpora lutea on either side of the uterus. This confirms the finding of Doyle \& Margolis and other workers, that the thread does not affect ovulation.

TABLE 1

NUMBER OF IMPLANTATIONS AND GORPORA LUTEA IN EXPERIMENTAL AND CONTROL HORNS IN TWENTY-EIGHT RATS WITH THE THREAD in situ

\begin{tabular}{|c|c|c|c|c|c|c|}
\hline \multirow{2}{*}{$\begin{array}{l}\text { Rat } \\
\text { No. }\end{array}$} & \multirow{2}{*}{$\begin{array}{l}\text { Type of thread } \\
\text { and position in } \\
\text { uterine horn }\end{array}$} & \multicolumn{2}{|c|}{ No. of implantations } & \multicolumn{2}{|c|}{ No. of corpora lutea } & \multirow{2}{*}{$\begin{array}{l}\text { Histological examination of } \\
\text { treated horns in sixteen females. } \\
\text { Localization of thread if seen }\end{array}$} \\
\hline & & $\begin{array}{c}\text { Sutured } \\
\text { horn }\end{array}$ & $\begin{array}{c}\text { Control } \\
\text { horn }\end{array}$ & $\begin{array}{l}\text { Sutured } \\
\text { horn }\end{array}$ & $\begin{array}{c}\text { Control } \\
\text { horn }\end{array}$ & \\
\hline \multirow{18}{*}{$\begin{array}{r}1 \\
2 \\
3 \\
4 \\
5 \\
6 \\
7 \\
8 \\
9 \\
10 \\
11 \\
12 \\
13 \\
14 \\
15 \\
16 \\
17\end{array}$} & Free; middle & 0 & 10 & - & _- & - \\
\hline & Free; middle & 0 & 4 & 7 & 8 & - \\
\hline & Attached; middle & 0 & 3 & 9 & 3 & - \\
\hline & Attached; middle & 0 & 7 & 3 & 7 & - \\
\hline & Attached; middle & 0 & 5 & 3 & 5 & Not seen \\
\hline & Attached; lower & 0 & 3 & 4 & 3 & Lumen \\
\hline & Attached; lower & 0 & 2 & 7 & 3 & - \\
\hline & Attached; lower & 0 & 3 & - & - & - \\
\hline & Attached; lower & 0 & 5 & 6 & 5 & Not seen \\
\hline & Attached; lower & 0 & 7 & 6 & 7 & - \\
\hline & Attached; lower & 0 & 5 & 3 & 5 & Lumen \\
\hline & Attached; lower & 0 & 9 & - & - & Lumen \\
\hline & Attached; lower & 0 & 1 & 2 & 3 & Submucosa \\
\hline & Attached; lower & 0 & 7 & - & 7 & - \\
\hline & Attached; lower & 0 & 4 & 5 & 4 & - \\
\hline & Attached; lower & 0 & 1 & 8 & 3 & Lumen \\
\hline & Attached; lower & 0 & 3 & 3 & 3 & - \\
\hline & $\begin{array}{l}\text { Total (17) } \\
\text { Mean/rat }\end{array}$ & $\begin{array}{l}0 \\
0\end{array}$ & $\begin{array}{l}79 \\
4 \cdot 6\end{array}$ & $\begin{array}{c}66 \\
4 \cdot 7\end{array}$ & $\begin{array}{c}66 \\
4 \cdot 7\end{array}$ & \\
\hline \multirow{12}{*}{$\begin{array}{l}18 \\
19 \\
20 \\
21 \\
22 \\
23 \\
24 \\
25 \\
26 \\
27 \\
28\end{array}$} & Free; middle & 1 & 6 & 6 & 7 & Not seen \\
\hline & Attached; middle & $3 *$ & 6 & 7 & 6 & Not seen \\
\hline & Attached; lower & 6 & 5 & - & - & Not seen \\
\hline & Attached; lower & 4 & 7 & 4 & 7 & - \\
\hline & Attached; lower & 1 & 4 & - & - & Lumen \\
\hline & Attached; lower & 5 & 5 & - & - & Submucosa \\
\hline & Attached; lower & 3 & 7 & 5 & 7 & Submucosa \\
\hline & Attached; lower & $1+1^{*}$ & 6 & 3 & 6 & Lumen \\
\hline & Attached; lower & $1+3^{*}$ & 4 & 4 & 4 & Lumen \\
\hline & Attached; lower & $3^{*}$ & 4 & - & - & Submucosa \\
\hline & Attached; middle & 2 & - & 7 & 6 & - \\
\hline & $\begin{array}{l}\text { Total (11) } \\
\text { Mean/rat }\end{array}$ & $\begin{array}{l}34 \\
3 \cdot 1\end{array}$ & $\begin{array}{c}54 \\
4.9\end{array}$ & $\begin{array}{l}36 \\
5 \cdot 1\end{array}$ & $\begin{array}{l}43 \\
6 \cdot 1\end{array}$ & \\
\hline
\end{tabular}

* Retarded or dying implantations.

Effect of withdrawal of the thread from the lumen of the horn

In two rats (not listed in Tables 1 and 2), with free ending sutures, the suture was found to have withdrawn so that it only reached the serosal and muscular part of the uterine wall but not its lumen. In both animals implantations (three and one, respectively) were found in the treated horn.

Effect of removing the suture on Day 3 of pregnancy

In all five rats in which the thread was removed on Day 3 of pregnancy 
implantations occurred in the treated horns (Table 2). This result is in agreement with the findings of Doyle \& Margolis (1964) who state that the antifertility effect of the thread manifests itself only after the 3rd day of pregnancy, i.e. on Days 4 to 5 when the blastocysts enter the uterus.

\section{Histological examination}

This was done in seven rats (see Table 1) with no implantation in the treated horn and in nine rats with implantation in that horn. The thread could be seen only in eleven females since it was sometimes lost during preparation of sections. Rats Nos. 22, 25 and 26 are particularly interesting. Implantations were found in the treated horn and in the sections the thread was seen to pass through the uterine lumen (Pl. 1, Fig. Ic). Thus, even passage of the thread through the uterine lumen does not prevent implantation in some rats.

TABLE 2

EFFECT OF REMOVAL OF THREAD ON 3RD DAY OF PREGNANGY ON NUMBER OF IMPLANTATIONS AND CORPORA LUTEA

\begin{tabular}{|c|c|c|c|c|}
\hline \multirow{2}{*}{$\begin{array}{l}\text { Rat } \\
\text { No. }\end{array}$} & \multicolumn{2}{|c|}{ No. of implantations } & \multicolumn{2}{|c|}{ No. of corpora lutea } \\
\hline & $\begin{array}{c}\text { Sutured } \\
\text { horn }\end{array}$ & $\begin{array}{c}\text { Control } \\
\text { horn }\end{array}$ & $\begin{array}{c}\text { Sutured } \\
\text { horn }\end{array}$ & $\begin{array}{c}\text { Control } \\
\text { horn }\end{array}$ \\
\hline $\begin{array}{l}1 \\
2 \\
3 \\
4 \\
5\end{array}$ & $\begin{array}{l}6 \\
5 \\
6 \\
3 \\
6\end{array}$ & $\begin{array}{l}9 \\
7 \\
6 \\
2 \\
6\end{array}$ & $\begin{array}{l}8 \\
6 \\
6 \\
6 \\
7\end{array}$ & $\begin{array}{l}9 \\
8 \\
7 \\
5 \\
6\end{array}$ \\
\hline
\end{tabular}

\section{Leucocytic infiltration in the treated horns}

Such infiltration of varying intensity was found in the lumen and mucosa of the treated horns in six out of seven rats in which no implantations had occurred. The infiltration extended not only over the site of the thread but also over the rest of the horn (Pl. 2, Figs. 3a and b). Only in one rat (No. 13) was infiltration absent, and here the thread, as shown histologically, passed through the submucosa only.

In rats with implantations in the treated horn the number of leucocytes in the lumen and mucosa was much smaller. In the three rats where the thread passed through the lumen usually only a narrow band of leucocytic infiltration surrounding the thread was found and a small number of leucocytes in the mucosa (Pl. 1, Fig. 2). In rat No. 18, a pronounced infiltration of leucocytes was found at the site of implantation and its surroundings. Thus implantation and leucocytic infiltration may occur side by side (Pl. 2, Figs. 4a and b).

\section{DISCUSSION}

Out of twenty-eight rats eleven had implantations in the treated horns. This is in contrast with the finding of Doyle \& Margolis (1963, 1964, 1965), Kar et al. (1964) and Marston \& Chang (1965), who found that the thread completely 


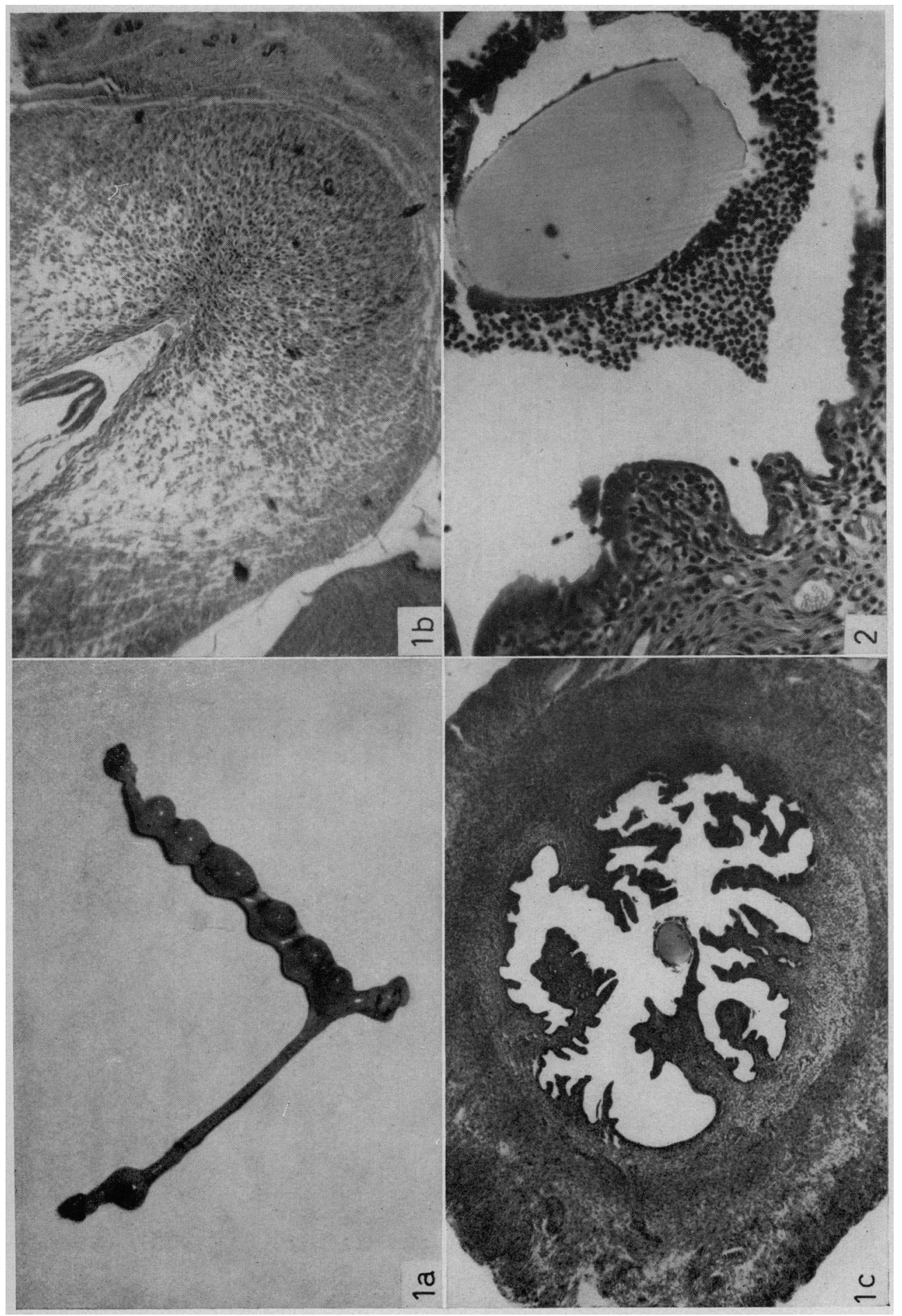

焉

象

范

芯 方

芯芯

$\stackrel{n}{=}$

롱

¿ே

焉

을

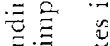

苍要

$\stackrel{\Xi}{=}$

$\ddot{\approx} \overline{5}$

ह

$\cong$

苛.

플

苋氖

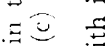

चें

胥的

डि

ชิ

范

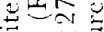

政要

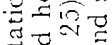

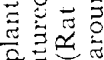

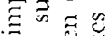

政志

프르를

$3 \overline{0} \div$

जी as

严要密

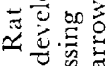

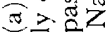

$\therefore \stackrel{\nabla}{*}{ }^{2}$

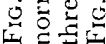




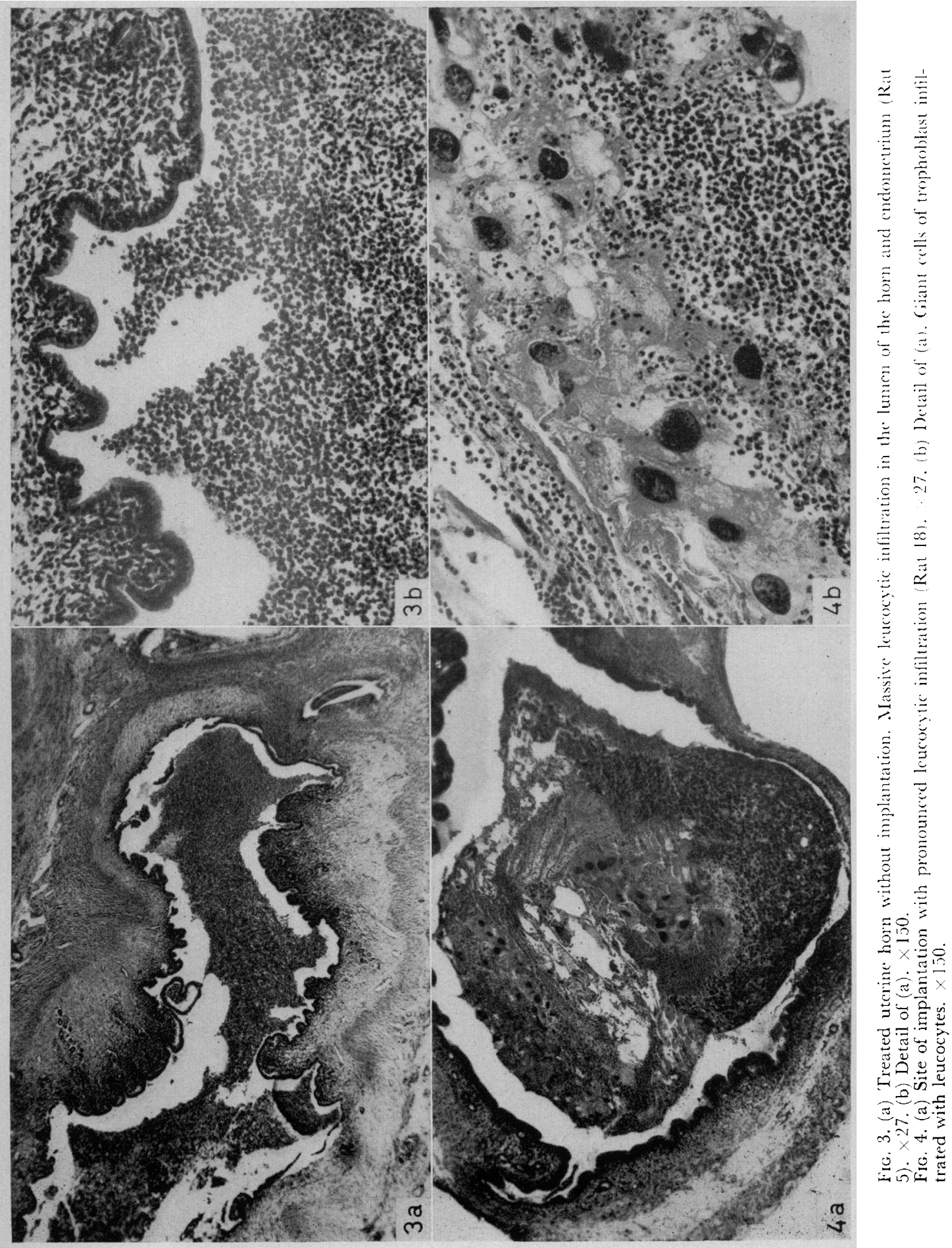


prevents implantation. Hence differences in methods must be considered. We did not use a silk thread but a black nylon ('Orsilon') one since this is more easily visible in the tissues. According to Doyle \& Margolis there is no difference in the effect of a silk thread. We do not believe that our results are due to the different material used, even though this problem deserves further attention. The length of the thread passing through the lumen might also play a role. This length was 5 to $8 \mathrm{~mm}$ in the experiments of Doyle \& Margolis and 12 to 15 $\mathrm{mm}$ in those of Kar et al. (1964). Greenwald used attached threads passing for $5 \mathrm{~mm}$ through the tissue of the horn. The length of the threads in our own experiments was 5 to $8 \mathrm{~mm}$ and thus differs only from those used by Kar et al. (1964).

Only threads passing through the lumen prevent implantation according to Greenwald. In our experiments it could be shown that even such threads do not always prevent implantation. It must be pointed out, however, that the number of implantations was decreased. Some of them were retarded, others showed signs of degeneration. This might be explained by a delay in nidation.

Some of our rats thus reacted in a similar way to rabbits. In rabbits (Adams \& Eckstein, 1965a, b) the suture decreases the number of implantations and has an unfavourable effect on the subsequent fate of those eggs that implant.

Leucocytic infiltration, in agreement with Greenwald, was found in treated horns mainly in the lumen and also in the uterine wall, if implantation was inhibited. No such infiltrations were found on the control side. In contrast to Greenwald, however, leucocytes were also found, even though to a lesser extent, in horns in which implantation did occur. Hence the relationship between the prevention and the occurrence of leucocytic infiltration is not qualitative but only quantitative. Exceptionally, a massive infiltration may occur in a macroscopically normally developing implantation site (rat No. 18, Pl. 2, Figs. 4a and $b$ ).

In addition, strain differences between our rats and those used by others may account for some of the reported differences.

\section{REFERENCES}

Adams, C. E. \& Eckstein, P. (1965a) Effect of intra-uterine silk threads on location and survival of conceptuses in the rabbit. J. Reprod. Fert. 9, 351 .

Adams, C. E. \& Eckstein, P. (1965b) The effect of intrauterine foreign bodies on pregnancy in the rabbit. Fert. Steril. 16, 508.

Doyle, L. L. \& Margolis, A. J. (1963) Intrauterine foreign body: Effect on pregnancy in the rat. Science, N.Y. 139, 833.

Doyle, L. L. \& Margolis, A. J. (1964) Intrauterine foreign body. I. Effect on reproductive processes in the rat. Fert. Steril. 15, 597.

Doyle, L. L. \& Margolis, A. J. (1965) Intra-uterine foreign body studies in rodents. Proc. 2nd int. Conf. Intrauterine Contraception, New York, p. 185.

GREenWALD, G. S. (1965) Interruption of pregnancy in the rat by a uterine suture. F. Reprod. Fert. 9, 9.

Kar, A. B., KamboJ, V. \& Datra, J. K. (1964) Prevention of delayed implantation in rats by means of an intrauterine foreign body. F. Reprod. Fert. 8, 139.

Kar, A. B., KamboJ, V. P., Goswami, A. \& Ghowdhury, S. R. (1965) Effect of an intra-uterine contraceptive suture on the uterus and fertility of rats. F. Reprod. Fert. 9, 317.

MARgolis, A. J. \& Doyle, L. L. (1964) Intrauterine foreign body. II. Inhibition of decidual response in the rat. Fert. Steril. 15, 607.

Marston, J. H. \& Chang, M. C. (1965) Action of intra-uterine bodies in the rat and rabbit. Proc. 2nd int. Conf. Intrauterine Contraception, New York, p. 242.

WrLcoxon, F. (1945) Individual comparisons by ranking methods. Biometr. Bull. 1, 80. 